Published in final edited form as:

Am J Physiol Lung Cell Mol Physiol. 2006 July ; 291(1): L58-L65.

\title{
Characterization of acid-signaling in rat vagal pulmonary sensory neurons
}

\author{
Qihai Gu and Lu-Yuan Lee \\ Department of Physiology, University of Kentucky Medical Center, Lexington, KY, USA
}

\begin{abstract}
Local tissue acidosis frequently occurs in airway inflammatory and ischemic conditions. The effect of physiological/pathophysiological-relevant low $\mathrm{pH}$ (7.0-5.5) on isolated rat vagal pulmonary sensory neurons was investigated using whole-cell perforated patch-clamp recordings. In voltageclamp recordings, vagal pulmonary sensory neurons exhibited distinct $\mathrm{pH}$ sensitivities and different phenotypes of inward current in responding to acidic challenge. The current evoked by lowering the $\mathrm{pH}$ of extracellular solution to 7.0 consisted of only a transient, rapidly inactivating component with small amplitude. The amplitude of this transient current increased when the proton concentration was elevated. In addition, a slow, sustained inward current began to emerge when $\mathrm{pH}$ was reduced to below 6.5. The I-V curve indicated that the transient component of acid-evoked current was carried predominantly by $\mathrm{Na}^{+}$. This transient component was dose-dependently inhibited by amiloride, a common blocker of acid-sensing ion channels (ASICs), whereas the sustained component was significantly attenuated by capsazepine, a selective antagonist of transient receptor potential vanilloid receptor subtype-1 (TRPV1). The two components of acid-evoked current also displayed distinct recovery kinetics from desensitization. Furthermore, in current-clamp recordings, transient extracellular acidification depolarized the membrane potential and generated action potentials in these isolated neurons. In summary, our results have demonstrated that low $\mathrm{pH}$ can stimulate rat vagal pulmonary sensory neurons through the activation of both ASICs and TRPV1. The relative roles of these two current species depend on the range of $\mathrm{pH}$ and vary between neurons.
\end{abstract}

\section{Keywords}

ASICs; TRPV1; low pH; lung; vagus

\section{INTRODUCTION}

Pulmonary interstitial acidosis develops when the production of $\mathrm{CO}_{2}$ is exceedingly high and/ or the elimination of $\mathrm{CO}_{2}$ from the lungs is hindered. Such changes can occur in both physiological (e.g., excise) and pathophysiological (e.g., chronic obstructive pulmonary disease) conditions $(6,43)$. Excessive production of lactic acid also occurs commonly during anaerobic metabolism such as during tissue ischemia or hypoxia. A recent study from our laboratory demonstrated that pulmonary C-fibers were activated by a bolus intravenous injection of lactic acid that lowered the $\mathrm{pH}$ in pulmonary venous blood to 7.1 (17). The fact that similar responses of $\mathrm{C}$-fibers were also evoked when the same molar concentration of other types of acids (formic acid, glycolic acid, etc) with almost identical $\mathrm{pKa}(\sim 3.8)$ as lactic acid

\footnotetext{
Address for correspondence: Lu-Yuan Lee, Ph.D. Department of Physiology University of Kentucky Medical Center 800 Rose Street Lexington, KY 40536-0298 U.S.A. Tel: (859) 323-6339 Fax: (859) 323-1070 E-mail: lylee@uky.edu.

GRANTS

This study was supported by grants from NIH HL-58686 and HL-67379, and the Kentucky Lung Cancer Research Program. Q. Gu is a Parker B. Francis Fellow in Pulmonary Research.
} 
were injected suggests a major role of $\mathrm{H}^{+}$ions in this action. However, we could not draw a more definitive conclusion because acid solution is also known to induce local release of potent autacoids that can activate these afferents (14).

Furthermore, local tissue acidosis is known to occur in a number of pathophysiological conditions such as inflammation, ischemia and carcinogenesis, in which extracellular $\mathrm{pH}$ $\left(\mathrm{pH}_{\mathrm{o}}\right)$ can decrease by more than two $\mathrm{pH}$ units $(4,30,42)$. Decrease of $\mathrm{pH}_{\mathrm{o}}$ is known to activate acid-sensing ion channels (ASICs) in both peripheral sensory and central neurons $(2,21,39$, 42). ASICs, a newly described class of ligand-gated channels, have been suggested to play important roles in various physiological/pathophysiological conditions, from sensory transmission (such as nociception, mechanosensation, and taste) to ischemia, retinal function, and learning-memory $(7,21,25,34,45)$. In addition, it has been demonstrated that protons can also directly activate transient receptor potential vanilloid receptor subtype-1 (TRPV1) (9, 19). The contributions of ASICs and/or TRPV1 to acid signaling have been recently demonstrated in the nociceptors $(2,5,10,13,28,33,36,44)$. However, little is known about the relative roles of these two types of ion channels in the response to different levels of acidity in vagal pulmonary sensory neurons.

In light of the existing knowledge described above and the information that is currently lacking, this study was carried out to characterize the acid-signaling properties in rat vagal pulmonary sensory neurons by using whole-cell perforated patch-clamp recordings.

\section{MATERIALS AND METHODS}

\section{Labeling vagal pulmonary sensory neurons with Dil}

Cell bodies of vagal sensory nerves arising from airways and lungs reside in nodose and intracranial jugular ganglia. These sensory neurons were identified by retrograde labeling from the lungs by using the fluorescent tracer DiI as described previously (15). Young adult SpragueDawley rats $(\sim 160 \mathrm{~g})$ were anesthetized with an intraperitoneal injection of pentobarbital (50 $\mathrm{mg} / \mathrm{kg}$ ) and intubated with a polyethylene catheter (PE 150) with its tip positioned in the trachea above the thoracic inlet. DiI was initially sonicated and dissolved in ethanol, diluted in saline $(1 \%$ ethanol $\mathrm{v} / \mathrm{v})$, and then instilled into the lungs $(0.2 \mathrm{mg} / \mathrm{ml} ; 0.2 \mathrm{ml} \times 2)$ with the animal's head tilted up at $\sim 30^{\circ}$.

\section{Isolation and culture of nodose and jugular ganglion neurons}

After 7-10 days, an interval previously determined to be sufficient for DiI to diffuse to the cell body, the rats were anesthetized with halothane inhalation and decapitated. The head was immediately immersed in ice-cold Hank's balanced salt solution. Nodose and jugular ganglia were extracted under a dissecting microscope and placed in ice-cold Dulbecco's minimal essential medium/F12 (DMEM/F12) solution. Each ganglion was desheathed, cut into 10 pieces, placed in $0.125 \%$ type IV collagenase, and incubated for $1 \mathrm{~h}$ in $5 \% \mathrm{CO}_{2}$ in air at $37^{\circ}$ C. The ganglion suspension was centrifuged $(150 \times \mathrm{g}, 5 \mathrm{~min})$ and supernatant-aspirated. The cell pellet was resuspended in $0.05 \%$ trypsin in Hanks' balanced salt solution for $5 \mathrm{~min}$ and centrifuged $(150 \times \mathrm{g}, 5 \mathrm{~min})$; the pellet was then resuspended in a modified DMEM/F-12 solution (DMEM/F-12 supplemented with 10\% (v/v) heat-inactivated fetal bovine serum, 100 units $/ \mathrm{ml}$ penicillin, $100 \mu \mathrm{g} / \mathrm{ml}$ streptomycin, and $100 \mu \mathrm{M}$ MEM nonessential amino acids) and gently triturated with a small bore fire-polished Pasteur pipette. The dispersed cell suspension was centrifuged $(500 \times \mathrm{g}, 8 \mathrm{~min})$ through a layer of $15 \%$ bovine serum albumin to separate the cells from the myelin debris. The pellets were resuspended in the modified DMEM/F-12 solution supplemented with $50 \mathrm{ng} / \mathrm{ml} 2.5 \mathrm{~S}$ nerve growth factor, plated onto poly-L-lysinecoated glass coverslips, and then incubated overnight $\left(5 \% \mathrm{CO}_{2}\right.$ in air at $\left.37^{\circ} \mathrm{C}\right)$. 


\section{Electrophysiology}

Whole-cell perforated patch-clamp recordings were carried out as described previously (15). Briefly, the coverslip containing the attached cells was placed in the center of a small recording chamber $(0.2 \mathrm{ml})$ that was perfused by gravity-feed (VC-6 perfusion valve controller; Warner Instruments, Hamden, CT) with standard extracellular solution (ECS). The chemical stimulants were applied by a pressure-driven drug delivery system (ALA-VM8; ALA Scientific Instruments, Westbury, NY), with its tip positioned to ensure that the cell was fully within the stream of the injectate. Recordings were made in the whole cell perforated patch configuration $(50 \mu \mathrm{g} / \mathrm{ml}$ gramicidin) using Axopatch 200B/pCLAMP 9.0 (Axon Instruments, Union City, $\mathrm{CA})$. The data were acquired at $5 \mathrm{kHz}$ and filtered at $2 \mathrm{kHz}$. The series resistance was usually in the range of 4-8 M $\Omega$ and was not compensated. The resting membrane potential was held at $-70 \mathrm{mV}$ except otherwise indicated. The experiments were performed at room temperature $\left(\sim 22^{\circ} \mathrm{C}\right)$.

\section{Solutions and chemicals}

Standard ECS contained (in mM): $136 \mathrm{NaCl}, 5.4 \mathrm{KCl}, 1.8 \mathrm{CaCl}_{2}, 1 \mathrm{MgCl}_{2}, 0.33 \mathrm{NaH}_{2} \mathrm{PO}_{4}$, 10 glucose, 10 HEPES, $\mathrm{pH}$ at 7.4. For solutions with $\mathrm{pH} \leq 6.0$, MES was used instead of HEPES for more reliable $\mathrm{pH}$ buffering. The intracellular solution contained (in $\mathrm{mM}$ ): 92 potassium gluconate, $40 \mathrm{KCl}, 8 \mathrm{NaCl}, 1 \mathrm{CaCl}_{2}, 0.5 \mathrm{MgCl}_{2}, 10 \mathrm{EGTA}, 10 \mathrm{HEPES}, \mathrm{pH}$ at 7.2.

DiI were purchased from Molecular Probes (Eugene, OR). DMEM/F12, trypsin and nerve growth factor were obtained from Invitrogen (Carlsbad, CA). All other chemicals were obtained from Sigma Chemical (St. Louis, MO). Stock solution of capsaicin (1 mM) was prepared in a vehicle of $10 \%$ Tween $80,10 \%$ ethanol, and $80 \%$ ECS. Stock solutions of amiloride and capsazepine were prepared in dimethyl sulfoxide at the concentration of 500 and $20 \mathrm{mM}$, respectively. The solutions of these chemicals at desired concentrations were prepared daily by dilution with ECS. No detectable effect of the vehicles of these chemical agents was found in our preliminary experiments.

\section{Statistical analysis}

Data were analyzed by a one-way analysis of variance (ANOVA). When the ANOVA showed a significant interaction, pair-wise comparisons were made with a post hoc analysis (Fisher's least significant difference). Results were considered significant when $P<0.05$. Data are means \pm SE.

\section{RESULTS}

A total of 93 pulmonary sensory neurons isolated from nodose and jugular ganglia of 23 rats were studied. The whole-cell capacitances of these neurons were in the range of 11.1-42.1 pF (average: $22.5 \pm 0.8 \mathrm{pF} ; n=93$ ); the majority of them ( 83 out of 93) were small in size (capacitance $\leq 30 \mathrm{pF}$ ). The average resting membrane potential of these neurons was $-64.4 \pm$ $1.3 \mathrm{mV}$ (range: -50 to $-82 \mathrm{mV} ; n=33$ ).

\section{Characteristics of acid-evoked inward current in rat vagal pulmonary sensory neurons}

At the holding potential of $-70 \mathrm{mV}$, a rapid drop of $\mathrm{pH}_{\mathrm{o}}$ from 7.4 evoked a transient, rapidly inactivating inward current (Fig. 1) which could be further differentiated based on activation and inactivation kinetics into a fast type (e.g., Fig. 1B) and slow type (e.g., Fig. 1C). In some of the neurons, the transient inward current was followed by a sustained component that did not desensitize during the presence of the acidic stimulus (e.g., Fig. 1, $A$ and $B$ ); whereas a small subsets of neurons showed only a sustained current upon the acid challenge without a transient component (e.g., Fig. 1D). 
As shown in Table 1, rat vagal pulmonary sensory neurons exhibited distinct $\mathrm{pH}$ sensitivities. A mild $\mathrm{pH}_{\mathrm{o}}$ drop to 7.0 activated $45.2 \%$ of these sensory neurons, and $\mathrm{pH} 6.5,6.0$, and 5.5 were able to activate $83.1 \%, 91.5 \%$, and $92.5 \%$ of these neurons, respectively. In response to acidic challenge, pulmonary sensory neurons also showed different phenotypes of inward currents. The current evoked by $\mathrm{pH} 7.0$ consisted of only the transient component with small amplitude (e.g., Fig. 1, $B$ and $C$ ). The amplitude of this transient current increased when the proton concentration increased (Table 1). Interestingly, the transient current apparently reached the maximum amplitude even at pH 6.5 in some neurons (e.g., Fig. 1A). In contrast, the sustained current increased its amplitude in a larger percentage of neurons when a lower $\mathrm{pH}_{\mathrm{O}}$ was applied (e.g., Fig. 1, $A$ and $B$; Table 1). Our data did not indicate a close association between the cell size of these sensory neurons and their $\mathrm{pH}$ sensitivities (Table 1).

In 45 of these neurons, we also tested their responses to capsaicin. Rapid application of capsaicin $(1 \mu \mathrm{M} ; 2-6 \mathrm{~s})$ evoked an inward current in $31(68.9 \%)$ neurons; the average amplitude of which was $1183.4 \pm 250.2 \mathrm{pA}$. The average whole-cell capacitance of these capsaicinsensitive neurons was $20.9 \pm 1.0 \mathrm{pF}$.

\section{Sodium is the charge-carrying ion of the transient component of acid-evoked current in rat vagal pulmonary sensory neurons}

The I-V curve was constructed by plotting the peak amplitude of the transient component of the current evoked by a $\mathrm{pH}_{\mathrm{o}}$ drop from 7.4 to 6.5 (or 6.0,5.5) at different membrane potentials. Neurons were voltage-clamped initially at $-80 \mathrm{mV}$ and then changed at a step of $+20 \mathrm{mV}$ every $5 \mathrm{~min}$. At each of these holding potentials, the current activated by the same low $\mathrm{pH}$ challenge applied for $6 \mathrm{~s}$ was recorded.

As shown in Fig. 2, the transient component of acid-evoked current in these pulmonary sensory neurons had a liner I-V relationship with a reversal potential at $\sim 65.4 \mathrm{mV}(n=8)$, which is close to the theoretical $\mathrm{Na}^{+}$equilibrium potential $\left(E_{\mathrm{Na}}=71.6 \mathrm{mV}\right.$ with extra- and intra-cellular solutions containing 136 and $8 \mathrm{mM} \mathrm{Na}^{+}$), indicating that the transient current evoked by low $\mathrm{pH}$ was selective for $\mathrm{Na}^{+}$ions.

\section{Effects of amiloride and capsazepine on acid-evoked current in rat vagal pulmonary sensory neurons}

To determine the contribution of ASICs to acid-evoked currents, we applied amiloride, a known blocker of ASICs. As illustrated in Fig. 3, 2-min pretreatment with amiloride dose-dependently attenuated the transient current evoked by low $\mathrm{pH}$ with $\mathrm{EC}_{50}$ at $32.6 \mu \mathrm{M}$. High dose of amiloride $(1 \mathrm{mM})$ significantly inhibited the peak transient current to a mean of $34.1 \pm 8.9 \%$ of the control responses (Fig. 3B; $n=7$ ). The effect of amiloride was reversible after 10-min washout in all seven neurons tested (e.g., Fig. 3A).

We also examined the relative contribution of TRPV1, another channel gated by protons $(9$, 19), to the acid-evoked current in these pulmonary sensory neurons. Pretreatment with capsazepine $(10 \mu \mathrm{M} ; 2 \mathrm{~min})$, a specific antagonist of TRPV1, significantly attenuated the sustained (e.g., Fig. 4, $A, B$ and $E$ ), but not the transient (e.g., Fig. 4, $A, C$ and $E$ ) component of the current evoked by low $\mathrm{pH}$. Consistent with what we demonstrated previously (15), this dose of capsazepine was able to completely abolish the capsaicin-evoked inward current in these sensory neurons (Fig., 4, $D$ and $F$ ). Both acid- and capsaicin-evoked currents were reversible 20-30 min after the termination of capsazepine treatment (Fig. 4).

In fourteen pulmonary sensory neurons, we examined the effects of amiloride and capsazepine in the same sensory neurons. As shown in Fig. 5, the transient component of acid-evoked current was primarily sensitive to amiloride, whereas the sustained component of which was 
mainly sensitive to capsazepine. There seemed no apparent interactions between these two chemicals when applied to the neurons simultaneously (Fig. 5).

\section{Recovery time course of acid-evoked current in rat vagal pulmonary sensory neurons}

To test the recovery from acid-induced desensitization, neurons were exposed to a low $\mathrm{pH}$ stimulus (6.5-5.5) for $6 \mathrm{~s}$, a duration sufficient to completely desensitize the transient component of acid-evoked current. Neurons were then bathed in the standard ECS (pH 7.4) for progressively shortening intervals before they were again challenged with the same low $\mathrm{pH}$ solution. The amplitudes of both components of the subsequent acid-evoked current were then compared with those of their corresponding controls, respectively. Our results showed that the transient current required $10-30$ s for a complete recovery $(n=7)$; whereas at least $60-120 \mathrm{~s}$ had to elapse before the sustained current fully recovered from desensitization $(n=$ 4) (Fig. 6, $A$ and $B$ ).

To compare the recovery time course between acid- and capsaicin-evoked currents, in a group of five neurons, we challenged cells with capsaicin with the similar protocol as described for low $\mathrm{pH}$. Short application (2-4 s) of $1 \mu \mathrm{M}$ capsaicin evoked a comparable or a slightly smaller inward current in the same neurons, whereas the full recovery time for capsaicin (6-8 min) was much longer compared to that for low $\mathrm{pH}$ (Fig. 6, $C$ and $D$ ).

\section{Effect of acid on the excitability of rat vagal pulmonary sensory neurons}

This series of study was carried out to test whether depolarization caused by transient extracellular acidification was sufficient to trigger action potentials in these isolated neurons. As shown in Fig. 7A, pH 7.0 failed to evoke a detectable inward current in this nodose ganglion neuron, but it induced a clear depolarization of the membrane potential (rest membrane potential: $-71 \mathrm{mV}$ ). When the $\mathrm{pH}_{\mathrm{O}}$ was dropped to 6.5 , action potentials were generated. In this particular neuron, when $\mathrm{pH}_{\mathrm{o}}$ decreasing from 6.5 to 6.0 and 5.5, the amplitudes of both the transient and sustained components of acid-evoked current in voltage-clamp recordings increased correspondingly. Similarly, in current-clamp mode, the temporal pattern of membrane depolarization also exhibited the transient and sustained components, coincided with those displayed in the voltage-clamp mode. The pattern of the action potentials evoked by capsaicin (e.g., Fig. 7B) or current injection (e.g., Fig. 7C) in the same neurons differed from that by low $\mathrm{pH}(n=5)$. Moreover, when $\geq 10 \mathrm{~s}$ elapsed, the depolarization/action potentials evoked by acidic challenge in current-clamp recordings was almost fully recovered from desensitization in all four neurons tested (e.g., Fig. 7D).

\section{DISCUSSION}

Our results showed that physiological/pathophysiological-relevant low $\mathrm{pH}$ (7.0-5.5) activated rat vagal pulmonary sensory neurons. In voltage-clamp recordings, these sensory neurons exhibited distinct $\mathrm{pH}$ sensitivities and different phenotypes of inward currents in response to low $\mathrm{pH}$ challenge. About half of these neurons responded to $\mathrm{pH} 7.0$ with a small, transient current. The amplitude of this transient current increased when the proton concentration was elevated. This transient current was predominantly carried by $\mathrm{Na}^{+}$, and was dose-dependently blocked by amiloride, indicating that it was mediated by ASICs. In addition, a slow, sustained inward current following the transient component began to emerge when $\mathrm{pH} \leq 6.5$ was applied. This sustained current was significantly attenuated by capsazepine, indicating that it was mediated primarily through TRPV1. In current-clamp recordings, transient extracellular acidification depolarized the membrane potential and generated action potentials in these sensory neurons. Furthermore, the inward currents and depolarization/action potentials mediated by these two different acid-activating channels displayed distinct activation, inactivation and recovery properties. 
ASICs, a novel class of ligand-gated cation channels activated by protons, belong to the amiloride-sensitive degenerin/epithelial sodium channel superfamily $(3,12,21,39,41)$. So far, four genes encoding six ASIC subunits have been cloned. Four of these subunits can form functional homomultimeric channels (45). The $\mathrm{pH}$ of half-maximal activation $\left(\mathrm{pH}_{0.5}\right)$ of these channels differs: ASIC1a, $\mathrm{pH}_{0.5}=6.2$ (39); $\mathrm{ASIC} 1 \mathrm{~b}$, a splice variant of ASIC1a, $\mathrm{pH}_{0.5}=5.9$ (10); ASIC2a, $\mathrm{pH}_{0.5}=4.4(29,40)$; and ASIC $3, \mathrm{pH}_{0.5}=6.5(34,38)$. Neither ASIC2b nor ASIC4 can form functional homomeric channel $(1,26)$. Whereas ASIC1a, ASIC1b, and ASIC2a display transient activation characteristics, ASIC3 responds to acid stimuli biphasically, with a quick desensitizing and a late sustained currents (16). ASICs have been shown to be expressed throughout the neurons of mammalian central and peripheral nervous systems $(2,21,42)$. Like other ligand-gated ion channels, functional ASICs can be formed by homomultimers as well as heteromultimers $(5,39)$. Different homomeric and heteromeric ASICs are known to have distinct $\mathrm{pH}$ sensitivity, ion selectivity, and channel kinetics (16). In dorsal root ganglion neurons, where many subtypes are expressed, native ASICs are believed to be heteromultimeric $(2,5)$. Our results have demonstrated for the first time that the acid-evoked inward currents in these pulmonary sensory neurons exhibited the properties of ASIC1 (e.g., Fig. 1B), ASIC2 (e.g., Fig. 1C), and ASIC3 (e.g., Fig. 1, $A$ and $B$ ) -like responses. However, we do not have more definitive evidence of their expressions in these neurons. The relative narrow physiological/pathophysiological range of low $\mathrm{pH}$ (7.0-5.5) applied in this study further limited our ability to measure the $\mathrm{pH}_{0.5}$ in these native neurons. Nevertheless, the reversal potential of the transient component, estimated from the current-voltage relationship (Fig. 2), was close to the theoretical $\mathrm{Na}^{+}$equilibrium potential. This $\mathrm{Na}^{+}$selectivity, together with amiloride sensitivity (Figs. 3 and 5) and rapid recovery from desensitization (Fig. 6) have provided the critical evidence of the activation of ASICs in these vagal pulmonary sensory neurons.

In this study, a slow, sustained inward current began to emerge when the extracellular $\mathrm{pH}$ is lowered to $\leq 6.5$, and the response did not inactivate during the presence of the acidic stimulus (e.g., Fig. 1, $A, B$ and $D$ ). The percentage of the neurons exhibiting this current and the amplitude of the current increased when the extracellular $\mathrm{pH}$ is reduced further; for example, when pH 5.5 (4-6 s) was applied, about $62 \%$ of neurons showed the sustained current (Table 1). Coincidently, a similar percentage of neurons ( $\sim 69 \%)$ responded to capsaicin $(1 \mu \mathrm{M} ; 2-6$ s) challenge. In contrast to its effect on the acid-evoked transient current, amiloride did not significantly affect the sustained current in these sensory neurons (Fig. 5). Instead, the latter was markedly attenuated by capsazepine (Figs. 4 and 5), a selective TRPV1 antagonist, indicating that it was mainly mediated by the activation of TRPV1 in these sensory neurons. Indeed, it has been known that, in addition to ASICs, protons can also directly activate TRPV1 $(9,19)$. The contribution of TRPV1 to the acid signaling has been extensively studied recently in the cutaneous nociceptive neurons $(9,35,36,37)$, where it has been shown that TRPV1 contributes to a major part of acid-induced nociception, especially the generation of the persistent pain under more severe acidification $(8,36)$.

Our results have shown that the ASICs-mediated transient component of acid-evoked inward current recovered completely from desensitization within $30 \mathrm{~s}$, whereas more than $60 \mathrm{~s}$ was required for the TRPV1-mediated sustained component to reach a full recovery (Fig. 6, $A$ and $B)$. It is noteworthy that the latter was still significantly shorter than that for the capsaicinevoked current (at least 6 min; Fig. 6, $C$ and $D$ ) which was known to be solely mediated by TRPV1 (e.g., Fig. 4, $D$ and $F$ ). This difference in the recovery time course between acid- and capsaicin-evoked TRPV1 responses may be, in part, due to the difference in the amplitudes of the peak currents evoked by these two chemical stimuli (Fig. 6). An alternative explanation could be that this difference was due to the different binding sites and different activation and inactivation kinetics of these two chemicals on this ion channel. It has been known that capsaicin binds to an intracellular site to activate TRPV1 (8), whereas proton has been 
suggested to interact with an extracellular site(s) on the channel complex (35). Indeed, several candidate sites located within putative extracellular loops of TRPV1 has been identified for such interactions, with two glutamate residuals E648 and E600 of particular interest $(8,18)$. Our study has also shown that low $\mathrm{pH}$ can cause the depolarization of membrane potential and generation of action potentials in these pulmonary sensory neurons. Interestingly, the acidevoked action potentials always fired at the transient (peak) but not the sustained (plateau) phase of the depolarization (e.g., Fig. 7, $A$ and $D$ ). A similar observation has also been reported in acid-induced activation of dorsal root ganglion neurons (27). It is believed that the TTXresistant $\mathrm{Na}^{+}$channels that are expressed in distinctly higher percentage in capsaicin-sensitive pulmonary neurons (22), plays a critical role in determining the activating properties of these neurons $(23,27)$.

The present study has shown that pH 5.5 stimulated the majority of pulmonary sensory neurons $(92.5 \%)$ through the activation of ASICs and/or TRPV1, which is in agreement with the observation made by Kollarik and Undem (20). These investigators recorded the extracellular action potential in an isolated airway nerve preparation, and demonstrated that the activation of guinea pig airway afferents by low $\mathrm{pH}$ was mediated by both slowly (TRPV1 dependent) and rapidly (TRPV1 independent) inactivating mechanisms. However, our results did not indicate a significant difference between pulmonary sensory neurons isolated from nodose and jugular ganglia in responding to acid challenge (not shown); nor did our data show a significant difference in cell size between the groups of neurons with different $\mathrm{pH}$ sensitivities (Table 1). Whether the differences in animal species (rat vs guinea pig) and experimental approaches contribute to the discrepancy between these two studies is not known.

It should be noticed that our data of acid-sensing properties in the present study was obtained from isolated pulmonary sensory neurons; whether there is a difference in the sensitivity to low $\mathrm{pH}$ between the sensory terminal and its neuronal soma remains to be determined.

However, it has been recognized that airway acidification induces cough and bronchoconstriction in humans and laboratory animals which has been suggested to result mainly from the release of neuropeptides from the acid-evoked activation of bronchopulmonary C-fibers $(20,31)$. Indeed, the majority of the vagal pulmonary afferent nerves are non-myelinated (C-) fibers. Stimulation of these C-fiber afferents is known to elicit a number of reflex responses mediated through the central and/or autonomic nervous systems, including bronchoconstriction, mucus hypersecretion, cough, dyspneic sensation and bronchial vasodilatation $(11,24)$. In addition, sensory neuropeptides such as tachykinins (e.g., substance $\mathrm{P}$, neurokinin A) and calcitonin gene-related peptide are synthesized in the cell bodies of these C-fibers and released locally from the sensory terminals upon stimulation. These peptides are known to act on a number of effector cells (e.g., airway smooth muscles, cholinergic ganglia, inflammatory cells, mucous glands) and produce potent local effects such as

bronchoconstriction, extravasation of macromolecules, and edema of airway mucosa in various species including humans $(24,32)$.

In summary, our results demonstrate that low $\mathrm{pH}$ can activate the majority of rat vagal pulmonary sensory neurons. The $\mathrm{pH}$ sensitivity and pattern of responses vary between neurons; and the acid signaling in these neurons is mediated through the activation of ASICs and TRPV1. Since the $\mathrm{pH}$ levels used in this study are well within the range of those reported for various pathophysiological conditions such as tissue inflammation and ischemia $(4,30)$, these findings may provide the information for elucidating the acid-signaling mechanisms in various airway diseases in which extracellular acidification is known to occur.

\section{ACKNOWLEDGEMENTS}

The authors thank Michelle E. Wiggers and Robert F. Morton for their technical assistance. 


\section{REFERENCES}

1. Akopian AN, Chen CC, Ding Y, Cesare P, Wood JN. A new member of the acid-sensing ion channel family. Neuroreport 2000;11:2217-2222. [PubMed: 10923674]

2. Alvarez de la Rosa D, Zhang P, Shao D, White F, Canessa CM. Functional implications of the localization and activity of acid-sensitive channels in rat peripheral nervous system. Proc Natl Acad Sci USA 2002;99:2326-2331. [PubMed: 11842212]

3. Benos DJ, Stanton BA. Functional domains within the degenerin/epithelial sodium channel (Deg/ ENaC) superfamily of ion channels. J Physiol 1999;520:631-644. [PubMed: 10545131]

4. Benson CJ, Sutherland SP. Toward an understanding of the molecules that sense myocardial ischemia. Ann N Y Acad Sci 2001;940:96-109. [PubMed: 11458710]

5. Benson CJ, Xie J, Wemmie JA, Price MP, Henss JM, Welsh MJ, Snyder PM. Heteromultimers of DEG/ENaC subunits form H+-gated channels in mouse sensory neurons. Proc Natl Acad Sci USA 2002;99:2338-2343. [PubMed: 11854527]

6. Berger KI, Ayappa I, Sorkin IB, Norman RG, Rapoport DM, Goldring RM. CO(2) homeostasis during periodic breathing in obstructive sleep apnea. J Appl Physiol 2000;88:257-264. [PubMed: 10642388]

7. Bianchi L, Driscoll M. Protons at the gate: $\mathrm{DEG} / \mathrm{ENaC}$ ion channels help us feel and remember. Neuron 2002;34:337-340. [PubMed: 11988165]

8. Caterina MJ, Julius D. The vanilloid receptor: a molecular gateway to the pain pathway. Annu Rev Neurosci 2001;24:487-517. [PubMed: 11283319]

9. Caterina MJ, Leffler A, Malmberg AB, Martin WJ, Trafton J, Petersen-Zeitz KR, Koltzenburg M, Basbaum AI, Julius D. Impaired nociception and pain sensation in mice lacking the capsaicin receptor. Science 2000;288:306-313. [PubMed: 10764638]

10. Chen CC, England S, Akopian AN, Wood JN. A sensory neuron-specific, proton-gated ion channel. Proc Natl Acad Sci USA 1998;95:10240-10245. [PubMed: 9707631]

11. Coleridge JC, Coleridge HM. Afferent vagal C fibre innervation of the lungs and airways and its functional significance. Rev Physiol Biochem Pharmacol 1984;99:1-110. [PubMed: 6695127]

12. Corey DP, Garcia-Anoveros J. Mechanosensation and the DEG/ENaC ion channels. Science 1996;273:323-324. [PubMed: 8685718]

13. Drew LJ, Rohrer DK, Price MP, Blaver KE, Cockayne DA, Cesare P, Wood JN. Acid-sensing ion channels ASIC2 and ASIC3 do not contribute to mechanically activated currents in mammalian sensory neurones. J Physiol 2004;556:691-710. [PubMed: 14990679]

14. Franco-Cereceda A, Kallner G, Lundberg JM. Cyclo-oxygenase products released by low pH have capsaicin-like actions on sensory nerves in the isolated guinea pig heart. Cardiovas Res 1994;28:365369.

15. Gu Q, Lin RL, Hu HZ, Zhu MX, Lee LY. 2-aminoethoxydiphenyl borate stimulates pulmonary C neurons via the activation of TRPV channels. Am J Physiol Lung Cell Mol Physiol 2005;288:L932941. [PubMed: 15653710]

16. Hesselager M, Timmermann DB, Ahring PK. pH Dependency and desensitization kinetics of heterologously expressed combinations of acid-sensing ion channel subunits. J Biol Chem 2004;279:11006-11015. [PubMed: 14701823]

17. Hong JL, Kwong K, Lee LY. Stimulation of pulmonary C fibres by lactic acid in rats: contributions of $\mathrm{H}^{+}$and lactate ions. J Physiol 1997;500:319-329. [PubMed: 9147320]

18. Jordt SE, Tominaga M, Julius D. Acid potentiation of the capsaicin receptor determined by a key extracellular site. Proc Natl Acad Sci USA 2000;97:8134-8139. [PubMed: 10859346]

19. Julius D, Basbaum AI. Molecular mechanisms of nociception. Nature 2001;413:203-210. [PubMed: 11557989]

20. Kollarik M, Undem BJ. Mechanisms of acid-induced activation of airway afferent nerve fibres in guinea-pig. J Physiol 2002;543:591-600. [PubMed: 12205192]

21. Krishtal O. The ASICs: signaling molecules? Modulators? Trends Neurosci 2003;26:477-483. [PubMed: 12948658]

22. Kwong K, Lee LY. Prostaglandin E2 potentiates a TTX-resistant sodium current in rat capsaicinsensitive vagal pulmonary sensory neurones. J Physiol 2005;564:437-450. [PubMed: 15705651] 
23. Lai J, Porreca F, Hunter JC, Gold MS. Voltage-gated sodium channels and hyperalgesia. Annu Rev Pharmacol Toxicol 2004;44:371-397. [PubMed: 14744251]

24. Lee LY, Pisarri TE. Afferent properties and reflex functions of bronchopulmonary C-fibers. Respir Physiol 2001;125:47-65. [PubMed: 11240152]

25. Lilley S, LeTissier P, Robbins J. The discovery and characterization of a proton-gated sodium current in rat retinal ganglion cells. J Neurosci 2004;24:1013-1022. [PubMed: 14762119]

26. Lingueglia E, de Weille JR, Bassilana F, Heurteaux C, Sakai H, Waldmann R, Lazdunski M. A modulatory subunit of acid sensing ion channels in brain and dorsal root ganglion cells. J Biol Chem 1997;272:29778-29783. [PubMed: 9368048]

27. Mamet J, Baron A, Lazdunski M, Voilley N. Proinflammatory mediators, stimulators of sensory neuron excitability via the expression of acid-sensing ion channels. J Neurosci 2002;22:1066210670. [PubMed: 12486159]

28. Mogil JS, Breese NM, Witty MF, Ritchie J, Rainville ML, Ase A, Abbadi N, Stucky CL, Seguela P. Transgenic expression of a dominant-negative ASIC3 subunit leads to increased sensitivity to mechanical and inflammatory stimuli. J Neurosci 2005;25:9893-9901. [PubMed: 16251436]

29. Price MP, Snyder PM, Welsh MJ. Cloning and expression of a novel human brain $\mathrm{Na}^{+}$channel. J Biol Chem 1996;271:7879-7882. [PubMed: 8626462]

30. Reeh PW, Steen KH. Tissue acidosis in nociception and pain. Prog Brain Res 1996;113:143-151. [PubMed: 9009732]

31. Ricciardolo FL. Mechanisms of citric acid-induced bronchoconstriction. Am J Med 2001;111:18S24S. [PubMed: 11749919]

32. Solway J, Leff AR. Sensory neuropeptides and airway function. J Appl Physiol 1991;71:2077-2087. [PubMed: 1663932]

33. Sugiura T, Dang K, Lamb K, Bielefeldt K, Gebhart GF. Acid-sensing properties in rat gastric sensory neurons from normal and ulcerated stomach. J Neurosci 2005;25:2617-2627. [PubMed: 15758172]

34. Sutherland SP, Benson CJ, Adelman JP, McCleskey EW. Acid-sensing ion channel 3 matches the acid-gated current in cardiac ischemia-sensing neurons. Proc Natl Acad Sci USA 2001;98:711-716. [PubMed: 11120882]

35. Tominaga M, Caterina MJ, Malmberg AB, Rosen TA, Gilbert H, Skinner K, Raumann BE, Basbaum AI, Julius D. The cloned capsaicin receptor integrates multiple pain-producing stimuli. Neuron 1998;21:531-543. [PubMed: 9768840]

36. Ugawa S, Ueda T, Ishida Y, Nishigaki M, Shibata Y, Shimada S. Amiloride-blockable acid-sensing ion channels are leading acid sensors expressed in human nociceptors. J Clin Invest 2002;110:11851190. [PubMed: 12393854]

37. Ugawa S, Ueda T, Yamamura H, Shimada S. In situ hybridization evidence for the coexistence of ASIC and TRPV1 within rat single sensory neurons. Brain Res Mol Brain Res 2005;136:125-133. [PubMed: 15893596]

38. Waldmann R, Bassilana F, de Weille J, Champigny G, Heurteaux C, Lazdunski M. Molecular cloning of a non-inactivating proton-gated $\mathrm{Na}^{+}$channel specific for sensory neurons. J Biol Chem 1997;272:20975-20978. [PubMed: 9261094]

39. Waldmann R, Champigny G, Bassilana F, Heurteaux C, Lazdunski M. A proton-gated cation channel involved in acid-sensing. Nature 1997;386:173-177. [PubMed: 9062189]

40. Waldmann R, Champigny G, Voilley N, Lauritzen I, Lazdunski M. The mammalian degenerin MDEG, an amiloride-sensitive cation channel activated by mutations causing neurodegeneration in Caenorhabditis elegans. J Biol Chem 1996;271:10433-10436. [PubMed: 8631835]

41. Waldmann R, Lazdunski M. H(+)-gated cation channels: neuronal acid sensors in the NaC/DEG family of ion channels. Curr Opin Neurobiol 1998;8:418-424. [PubMed: 9687356]

42. Waldmann R, Champigny G, Lingueglia E, De Weille JR, Heurteaux C, Lazdunski M. H(+)-gated cation channels. Ann N Y Acad Sci 1999;868:67-76. [PubMed: 10414282]

43. Wasserman K, Whipp BJ, Casaburi R, Beaver WL. Carbon dioxide flow and exercise hyperpnea. Cause and effect. Am Rev Respir Dis 1977;115:225-237. [PubMed: 326113]

44. Xie J, Price MP, Berger AL, Welsh MJ. DRASIC contributes to $\mathrm{pH}$-gated currents in large dorsal root ganglion sensory neurons by forming heteromultimeric channels. J Neurophysiol 2002;87:28352843. [PubMed: 12037186] 
45. Xiong ZG, Zhu XM, Chu XP, Minami M, Hey J, Wei WL, MacDonald JF, Wemmie JA, Price MP, Welsh MJ, Simon RP. Neuroprotection in ischemia: blocking calcium-permeable acid-sensing ion channels. Cell 2004;118:687-698. [PubMed: 15369669] 


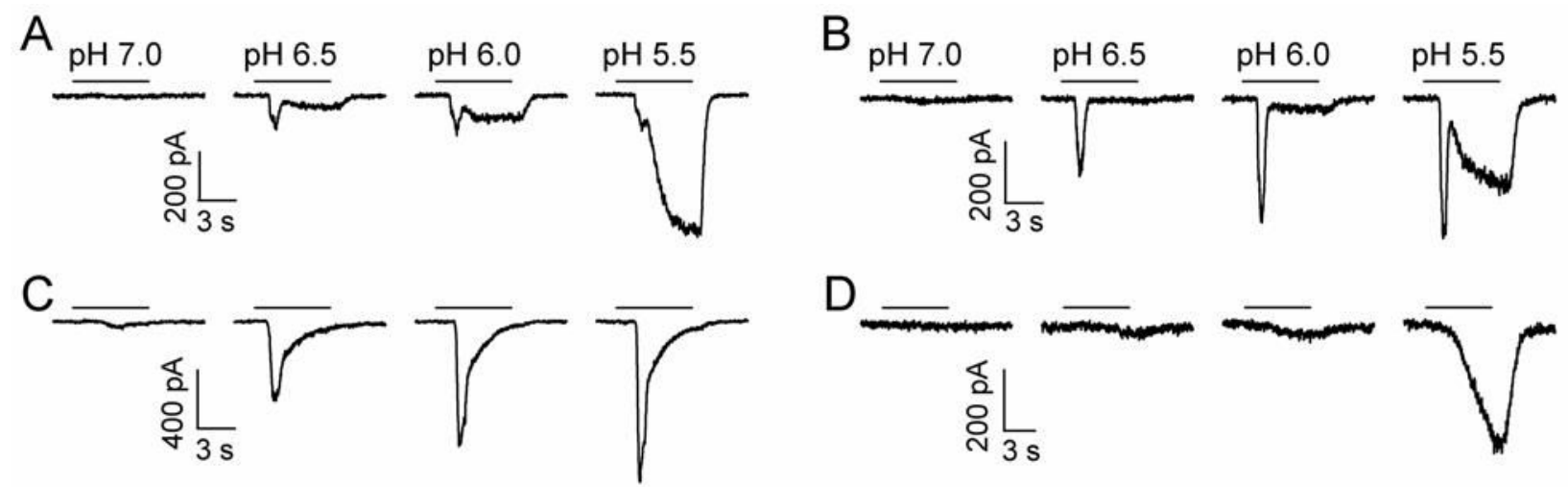

Fig. 1.

Representative acid-evoked whole cell inward currents in rat vagal pulmonary sensory neurons. Low $\mathrm{pH}$ with increasing proton concentrations were applied for $6 \mathrm{~s}$ (as indicated by the horizontal bars) to four different jugular ganglion neurons. The cell capacitances for the neurons in $A, B, C$, and $D$ were $24.2,23.1,15.6$, and $11.1 \mathrm{pF}$, respectively. Note distinct $\mathrm{pH}$ sensitivities and different phenotypes of inward currents in response to acidic challenges. 

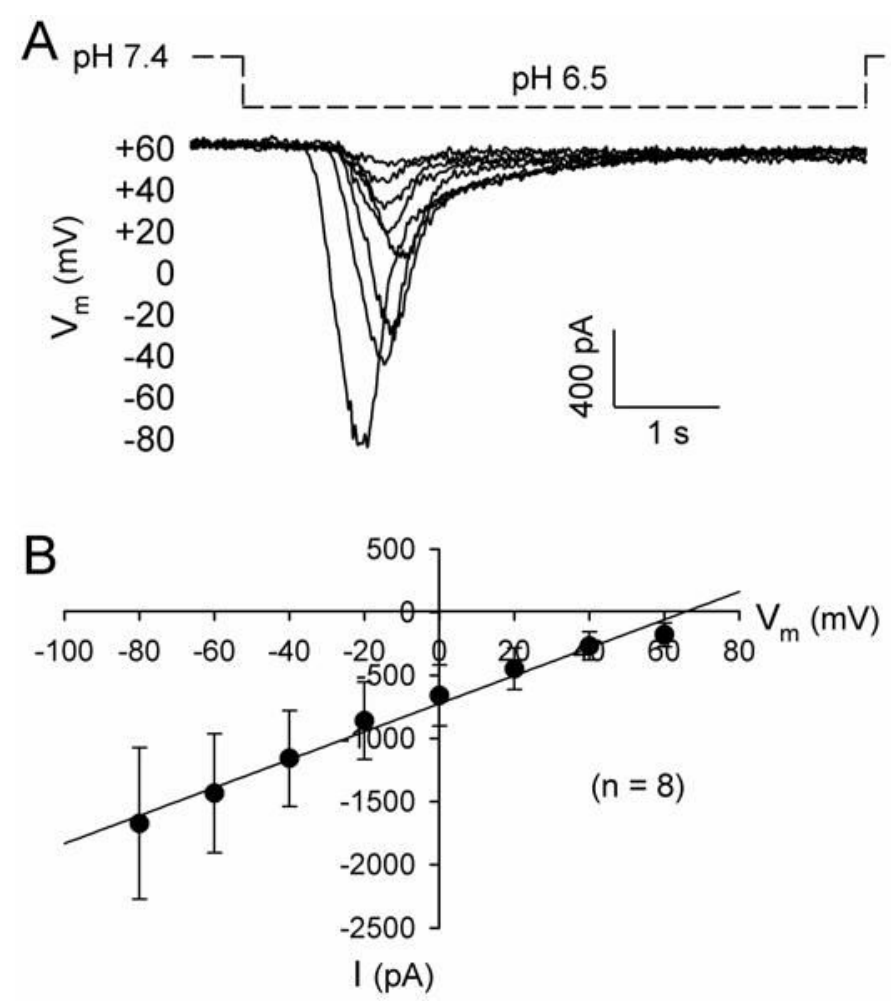

Fig. 2.

Acid-evoked transient inward currents at different membrane potentials in rat vagal pulmonary sensory neurons. A: representative records illustrating $\mathrm{pH} 6.5$-evoked transient currents in a jugular neuron $(23.2 \mathrm{pF})$ voltage clamped at the membrane potentials indicated in the figure. These membrane voltages were held for $90 \mathrm{~s}$ before the acid application to ensure any voltagegated conductance were inactivated. $\mathrm{V}_{\mathrm{m}}$, membrane potential. $B$ : current-voltage relationship of low $\mathrm{pH}(6.5-5.5 ; 6 \mathrm{~s})$-evoked transient currents from eight sensory neurons; the reversal potential was estimated at $\sim 65.4 \mathrm{mV}$. I, peak inward current evoked by acid application. Data represent means $\pm \mathrm{SE}$. 

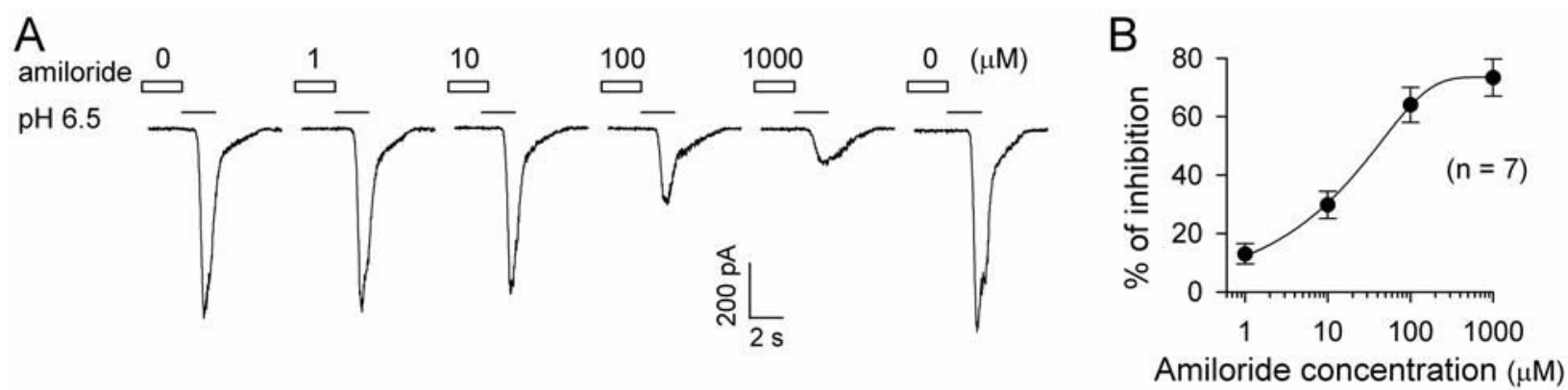

Fig. 3.

Effect of amiloride on the acid-evoked transient inward currents in rat vagal pulmonary sensory neurons. $A$ : representative records illustrating $\mathrm{pH} 6.5$-evoked transient currents in the absence and presence of a 2-min pretreatment of increasing concentration of amiloride in a jugular neuron $(36.5 \mathrm{pF})$. $B$ : group data showing the inhibitory effect of amiloride on low $\mathrm{pH}(6.5-$ $5.5 ; 2-6$ s) -evoked transient currents from seven sensory neurons; Chapman fit: $\mathrm{EC}_{50}, 32.6$ $\mu \mathrm{M}$. 

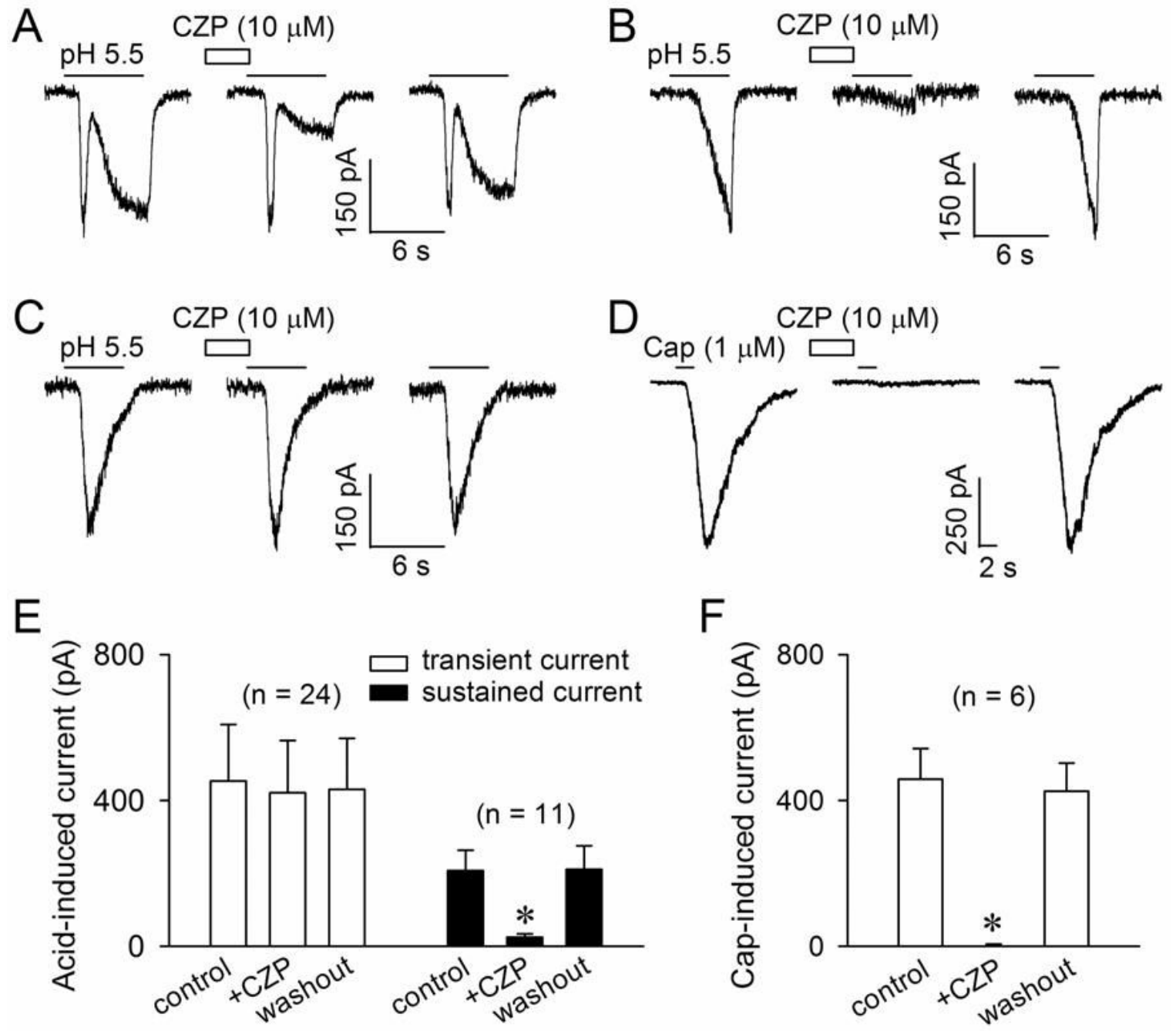

Fig. 4.

Effect of capsazepine on the acid- and capsaicin-evoked currents in rat vagal pulmonary sensory neurons. $A, B$ and $C$ : representative records illustrating the effect of capsazepine (CZP; $10 \mu \mathrm{M} ; 2 \mathrm{~min}$ ) pretreatment on pH 5.5 (4-6 s) -evoked inward currents in nodose (29 pF), jugular $(15.6 \mathrm{pF})$, and nodose $(18.6 \mathrm{pF})$ neurons, respectively. $D$ : representative records illustrating the effect of $\mathrm{CZP}(10 \mu \mathrm{M} ; 2 \mathrm{~min})$ on capsaicin (Cap; $1 \mu \mathrm{M}, 2 \mathrm{~s})$-evoked currents in a jugular neuron $(15.9 \mathrm{pF}) . E$ and $F$ : group data showing the effect of CZP on the inward currents evoked by low $\mathrm{pH}(6.5-5.5 ; 4-6 \mathrm{~s})$ and capsaicin $(1 \mu \mathrm{M} ; 2-4 \mathrm{~s})$, respectively. $* P<$ 0.05 as compared with the corresponding control. Data represent means \pm SE. 

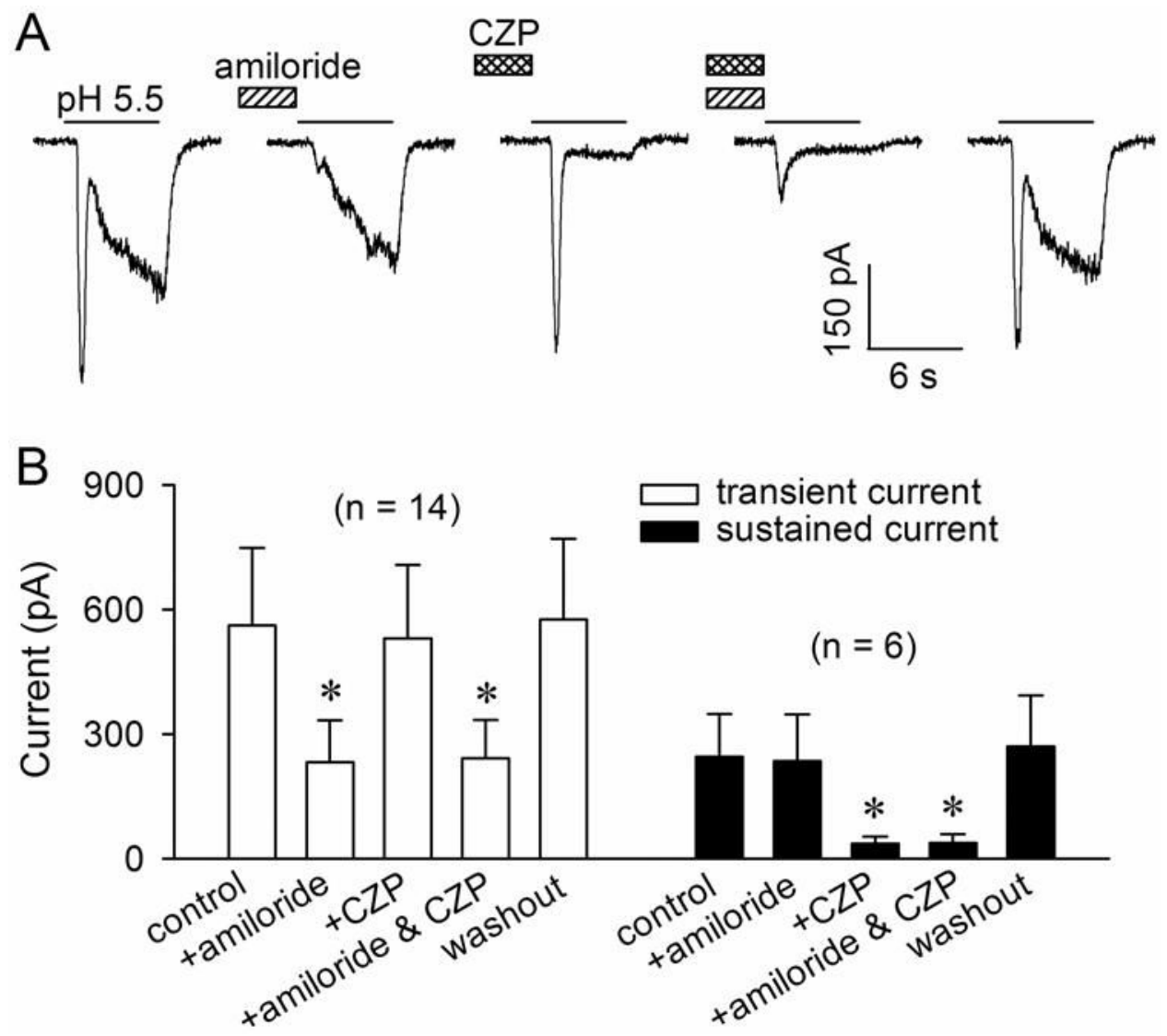

Fig. 5.

Effects of amiloride and capsazepine on the acid-evoked currents in the same rat vagal pulmonary sensory neurons. $A$ : representative records illustrating the effects of amiloride (100 $\mu \mathrm{M} ; 2 \mathrm{~min}$ ) and capsazepine (CZP; $10 \mu \mathrm{M}, 2 \mathrm{~min})$ on $\mathrm{pH} 5.5$ (6 s)-evoked inward currents in a jugular neuron $(23.1 \mathrm{pF}) . B$ : group data showing the effects of 2-min pretreatment with amiloride $(100 \mu \mathrm{M})$ and $\mathrm{CZP}(10 \mu \mathrm{M})$ on both transient and sustained components evoked by low pH (6.5-5.5; $6 \mathrm{~s}) . * P<0.05$ as compared with the corresponding control. Data represent means \pm SE. 
A

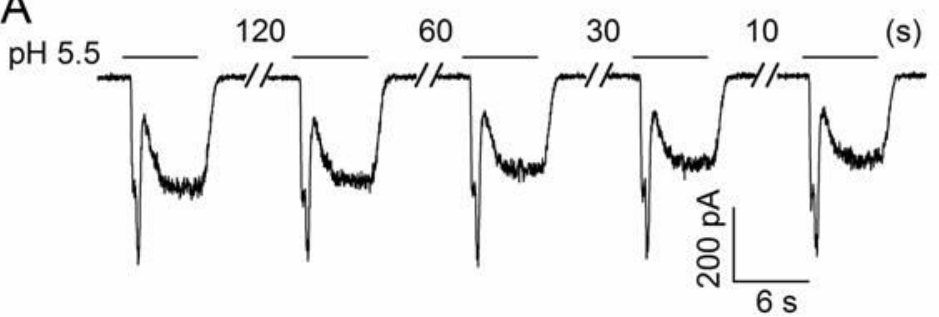

C

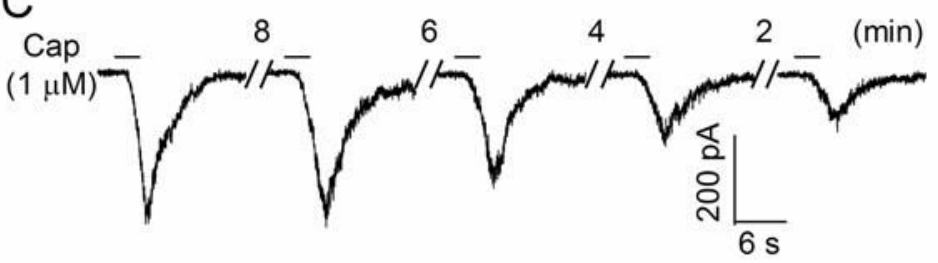

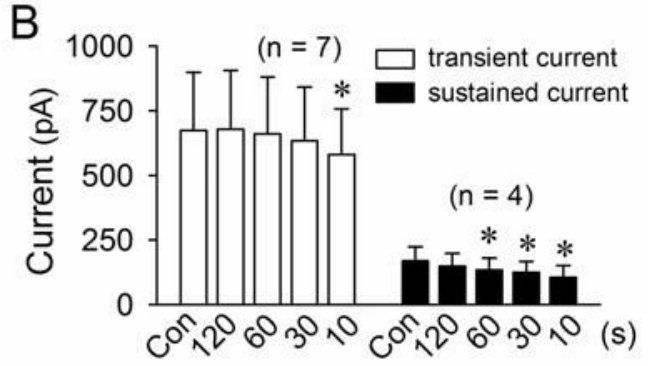

$\mathrm{D}$

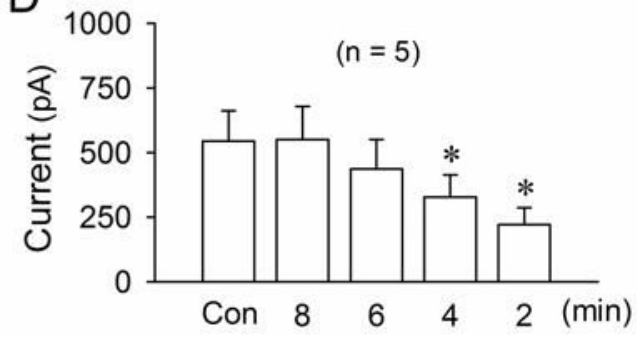

Fig. 6.

Different recovery kinetics of acid- and capsaicin-evoked currents in rat vagal pulmonary sensory neurons. $A$ and $C$ : inward currents evoked by repeated application of low pH $(5.5 ; 6$ s) and capsaicin (Cap; $1 \mu \mathrm{M}, 3 \mathrm{~s})$, respectively, at different intervals in the same pulmonary sensory neuron (nodose; $24.7 \mathrm{pF}$ ). $B$ and $D$ : group data showing the different recovery kinetics of acid- $(6.5-5.5 ; 6 \mathrm{~s})$ and capsaicin- $(1 \mu \mathrm{M} ; 2-4 \mathrm{~s})$ evoked currents in these sensory neurons, respectively. ${ }^{*} P<0.05$ as compared with the corresponding control (Con). Data are means \pm SE. 
A $\quad \mathrm{pH} 7.0$

$\left.\begin{array}{lr} & 80 \\ \text { है } & 40 \\ & 0 \\ >^{E} & -40 \\ -80\end{array}\right]$

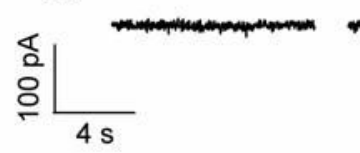

$\mathrm{pH} 6.5$
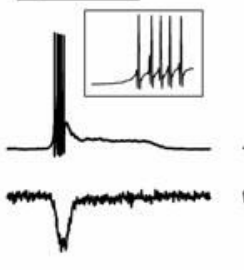

$\mathrm{pH} 6.0$
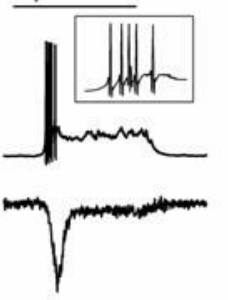
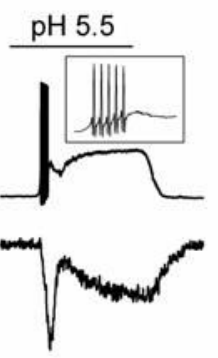

B Cap $(1 \mu \mathrm{M})$
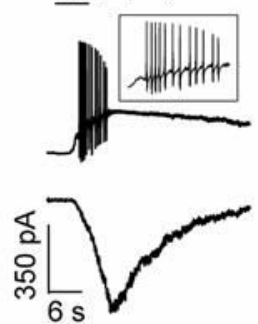

C
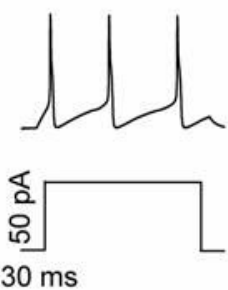

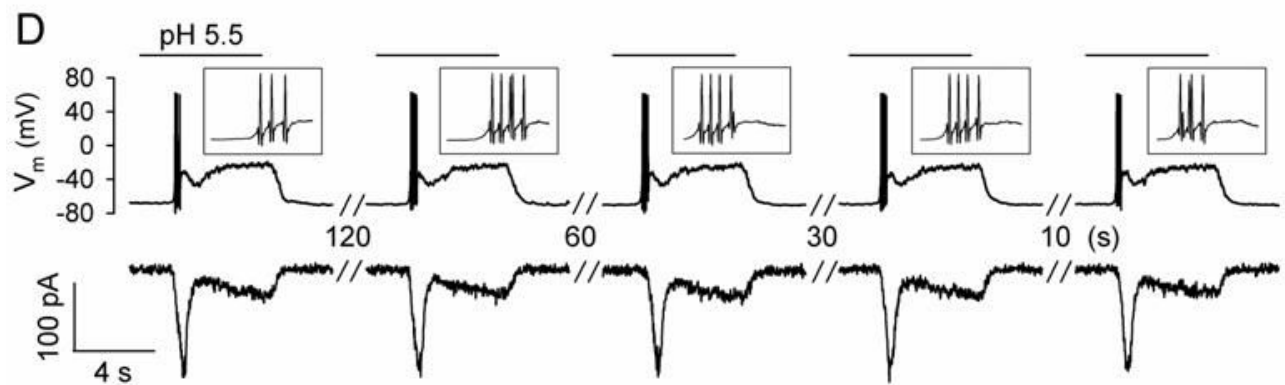

Fig. 7.

Changes in membrane potential (current-clamp) and inward current (voltage-clamp) in response to different stimuli in rat vagal pulmonary sensory neurons. $A$ and $B$ : acid- (pH 7.05.5; $6 \mathrm{~s}$ ) and capsaicin- (Cap; $1 \mu \mathrm{M}, 6 \mathrm{~s})$, respectively, evoked changes in membrane potential $\left(\mathrm{V}_{\mathrm{m}}\right.$; upper traces; current clamp) and inward current (lower traces; voltage clamp). $C$ : action potentials (upper trace) evoked by a $50 \mathrm{pA}$ current injection (198-ms duration; lower trace). $A, B$ and $C$ were recorded from a single nodose neuron $(23.3 \mathrm{pF}) . D$ : action potentials (upper traces) and inward currents (lower traces) evoked by pH 5.5 (6 s) challenge at different intervals in a jugular neuron $(30.1 \mathrm{pF})$. Insets, the action potentials triggered by various stimuli are shown on a large scale. 


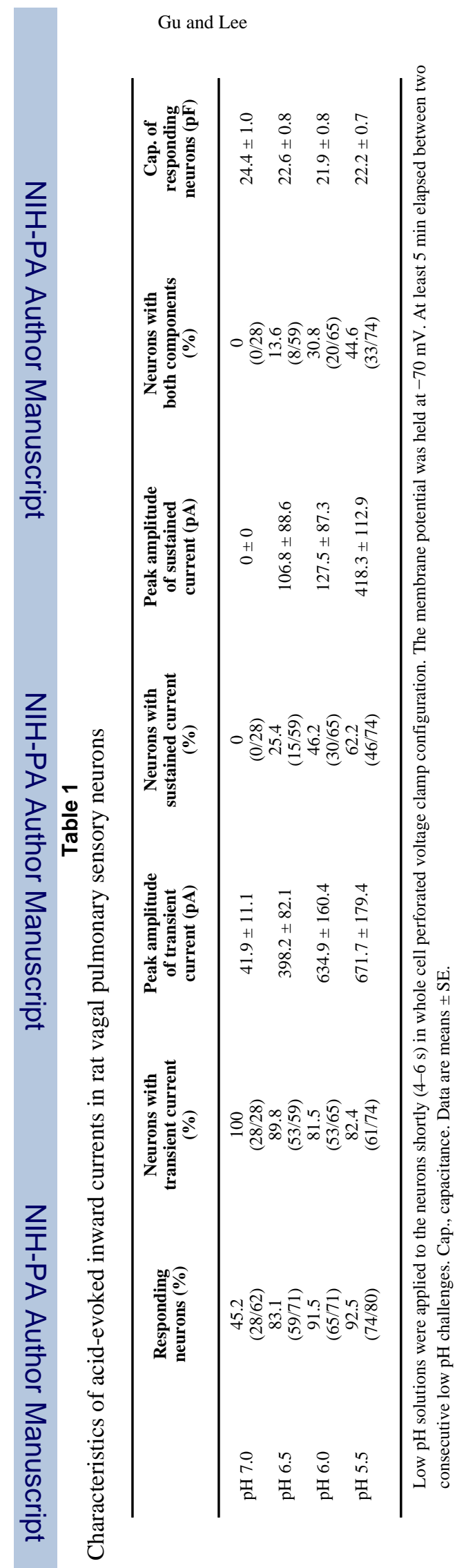

Page 18 